\title{
СЕРВЕР ДИСТАНЦЙНОГО НАВЧАННЯ БДМУ - ЕФЕКТИВНИЙ ІНСТРУМЕНТ ОРГАНІЗАЦІЇ ТА КОНТРОЛЮ САМОСТІЙНОЇ РОБОТИ СТУДЕНТІВ
}

\author{
Т. М. Бойчук, І. В. Геруш, В. М. Ходоровський \\ Буковинський державний медичний університет
}

\section{BSMU SERVER FOR DISTANCE LEARNING - AN EFFECTIVE TOOL FOR ORGANIZATION AND CONTROL OF STUDENTS' INDEPENDENT WORK}

\author{
T. M. Boychuk, I. V. Herush, V. M. Khodorovskyi \\ Bukovynian State Medical University
}

\begin{abstract}
У статті висвітлені окремі аспекти впровадження інформаційно-комунікаційних технологій в організацію і керівництво самостійною роботою студента шляхом використання системи управління навчанням “MOODLE" на прикладі сервера дистанційного навчання Буковинського державного медичного університету.
\end{abstract}

The article adduces some aspects of the implementation of information and communication technologies in the organization and management of independent work of students using learning management system «MOODLE» based on the example of server for distance learning of Bukovynian State Medical University.

Вступ. Серед пріоритетних напрямів державної політики щодо розвитку вищої освіти в контексті євроінтеграції України визначено проблему постійного підвищення якості освіти, модернізацію ії змісту та форм організації навчально-виховного процесу. Бурхливе зростання потоку наукової інформації, обсяг якої збільшується 3 кожним роком, спонукає шукати нові, більш ефективні технології, способи і засоби навчання, які дозволили б дати більше інформації за ту ж одиницю навчального часу і піднести їі більш яскраво і доступно, щоб вона легше сприймалася і краще запам'ятовувалася [2]. Застосування інформаційнокомунікаційних технологій (ІКТ) відноситься до числа тих факторів, які сприяють підвищенню інтенсивності та якості процесу навчання.

На сьогодні можна констатувати успішність застосування IКТ на всіх етапах навчального процесу від подання нового матеріалу до контролю набутих знань, умінь і навичок [1]. У даній статті розглядається впровадження IКТ в організацію і керівництво самостійною роботою студента шляхом використання системи управління навчанням "MOODLE” на прикладі сервера дистанційного навчання Буковинського державного медичного університету.

Основна частина. Самостійна робота студента є однією з найважливіших складових навчального про- цесу, під час якої відбувається формування знань, умінь і навичок, забезпечується засвоєння студентом прийомів пізнавальної діяльності, формується інтерес до творчої роботи i, в кінцевому рахунку, здатність вирішувати творчі та наукові завдання. У зв'язку з цим планування, організація та реалізація роботи студента за відсутності викладача є одними 3 найважливіших завдань навчання студента у вищому навчальному закладі. Для того щоб самостійна робота студента була ефективною, необхідна наявність таких умов:

- оптимальне співвідношення обсягів аудиторної та самостійної роботи;

- методично правильно організована робота студента в аудиторії і поза нею;

- усвідомлення студентами необхідності самостійної роботи;

- забезпечення студентів необхідними навчальними та наочними матеріалами з метою перетворення самостійної роботи в творчий процес;

- контроль за ходом самостійної роботи й наявність заходів, що заохочують студентів до ії якісного виконання.

Виконання першої умови залежить від якісно складеного навчального плану, в якому врахована не тільки правильна послідовність вивчення окремих дисциплін,

(c) Т. М. Бойчук, І. В. Геруш, В. М. Ходоровський 
але й досягнуто оптимальне співвідношення між аудиторною і самостійною роботою.

У реалізації інших умов можуть допомогти IKT, зокрема система управління навчанням "MOODLE" [3]. MOODLE (Modular Object-Oriented Dynamic Learning Environment) - це віртуальне навчальне середовище, яке являє собою мережеву програмну оболонку для створення електронних навчально-методичних комплексів. За допомогою цієї системи студент може дистанційно, через Інтернет, ознайомитися 3 навчальним матеріалом, який подається у вигляді різнотипних інформаційних ресурсів (текст, відео, анімація, презентація, електронний посібник), виконати завдання та відправити результати їх виконання на перевірку викладача.

У Буковинському державному медичному університеті впроваджено використання системи “MOODLE” у навчальному процесі у 2010 році і реалізовано у вигляді сервера дистанційного навчання (moodle.bsmu.edu.ua). На сервері дистанційного навчання для кожної навчальної дисципліни створені електронні навчальні курси, які містять організаційно-методичні та навчально-довідкові блоки, а також засоби самоконтролю та перевірки знань студентів (рис. 1).

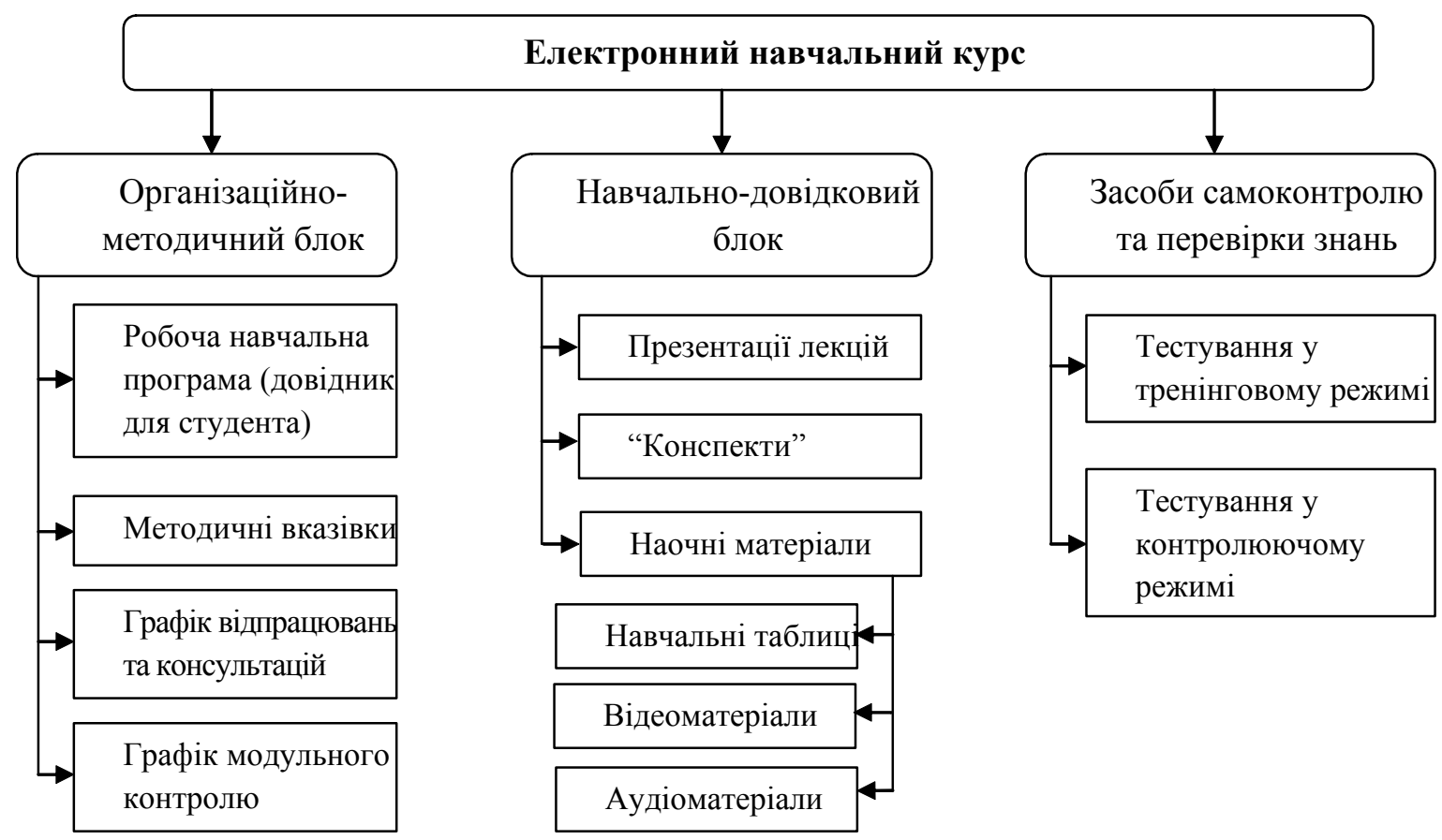

Puc. 1. Структурна схема електронного навчального курсу на сервері дистанційного навчання БДМУ.

Організаційно-методичний блок електронного навчального курсу забезпечує умову щодо методичної організації самостійної роботи студента як при вивченні дисципліни в цілому (інформація щодо структури, цілі та змісту дисципліни, принципів оцінювання, календарних та тематичних планів занять, графіків консультацій, проміжних та підсумкових контролів), так і при підготовці до конкретного навчального заняття (інформація щодо актуальності теми заняття, його тривалості, навчальної мети, питання для самоконтролю, список рекомендованої навчальної літератури).

Навчально-довідковий блок складається із структурованих електронних навчальних матеріалів, зміст яких надає студенту теоретичні відомості з теми заняття у повному обсязі (презентаціїлекцій, “конспекти"). Мультимедійні можливості системи "MOODLE" дозволяють максимально унаочнити навчальний матеріал у вигляді навчальних таблиць, відео- та аудіороликів тощо. Це дає змогу посилити інтерес студентів до навчального матеріалу, покращити його засвоєння, а на практичному (семінарському) занятті оптимальніше використати відведений час. Крім того, мультимедійні ресурси дозволяють студентам вже на етапі підготовки до навчального заняття ознайомитися $33 \mathrm{D}$-анатомічними моделями, у відеорежимі побачити методики проведення клінічного чи лабораторно-інструментального обстеження пацієнта, хід виконання експериментів, оперативних втручань, прослухати аудіолекції.

На сервері дистанційного навчання БДМУ реалізується умова щодо перетворення самостійної роботи студента в творчий процес шляхом використання таких видів діяльності, як “Wiki”, “Завдання” та "Урок".

"Wiki" - модуль активних елементів, призначений для групової роботи, який дозволяє учасникам елек- 
тронного навчального курсу працювати разом та одночасно над одним документом з різних комп'ютерів. Даний модуль веде облік змін документа, їх “авторство”, дозволяє порівнювати редакції та відновлювати більш ранні версії. Тобто це засіб для створення колективного документа, історія змін до якого зберігається та персоніфікується. На практиці "Wiki” використовується для написання академічною групою реферативного огляду щодо сучасних методів діагностики та підходів лікування. У процесі підготовки огляду викладач має змогу оцінити як роботу групи в цілому, так і індивідуальний внесок кожного студента.

“Завдання” - це вид діяльності студента, результатом якої є створення та завантаження на сервер файлу будь-якого формату або створення тексту безпосередньо в системі Moodle (за допомогою вбудованого візуального редактора). Завдання може полягати в інтерпретації студентом результатів лабораторних та клініко-інструментальних досліджень, аналізі схеми фармакотерапії при конкретній клінічній ситуації, проведенні генеричної заміни брендових лікарських препаратів тощо. Викладач може оперативно перевірити складені студентом файли або тексти, прокоментувати їх i, при необхідності, запропонувати доопрацювати в певних напрямках. Викладач може відкрити посилання на файли, які складені учасниками курсу, і зробити ці роботи предметом обговорення у форумі.

Інший цікавий вид діяльності на сервері дистанційного навчання БДМУ - це елемент “Урок”. Це інтерактивний елемент, за допомогою якого теоретичний матеріал подається порційно (слайдами) 3 періодичною перевіркою розуміння отриманої інформації за допомогою тестів. Викладач визначає переходи між слайдами, що дає широкі можливості для логістики вивчення матеріалу. Так, при неправильних відповідях система може направити студента саме до того слайда, де описується відповідь на це питання i, таким чином, спонукає його ще раз перечитати матеріал. Ця можливість також створює умови для різноглибинної подачі матеріалу. Викладач має можливість визначити проходження уроку за різними гілками складності, надаючи студентам можливість обирати мінімальне або глибше засвоєння матеріалу. Проходження кожного уроку оцінюється за результатами відповідей на тестові завдання, що стимулює пройти його повторно та покращити свій результат.

Важливим етапом самостійної роботи студента $є$ самоконтроль. Для цього в електронних навчальних курсах в кінці кожного тематичного розділу дисцип- ліни створений елемент “Тестові завдання для самоконтролю”, який дає можливість студенту пройти онлайн-тестування як з обмеженням по часу (контролюючий режим), так і без нього (тренінговий режим). У тренінговому режимі студент має змогу перевірити відповідь на поточне завдання, а також отримати підказку. Тренінговий режим самоконтролю дозволяє студенту самостійно виявляти проблеми в структурі своїх знань та вживати заходів щодо їх ліквідації. Викладач має змогу перевірити результати тестування студентів, побачити кількість спроб та затрачений час, визначити найбільш “легкі” та “проблемні” для студентів тестові завдання. Останнє дозволяє викладачу напередодні проведення навчального заняття адаптувати план його проведення, а саме правильно визначити акценти як в розрізі групи, так i в розрізі конкретного студента, що дозволяє індивідуалізувати навчальний процес.

Сервер дистанційного навчання БДМУ дозволяє сформувати та надати студенту не тільки організаційно-методичний та навчально-довідковий контент, а й забезпечує контроль самостійної діяльності студента. Зокрема викладач може одержати інформацію щодо кількості відвідувань сервера, часу перебування в електронному навчальному курсі, переліку опрацьованих ресурсів та елементів курсу, кількості та якості виконаних завдань. Викладачу доступні результати діяльності конкретного студента, а також аналіз роботи академічної групи в цілому. Така інформація дозволяє викладачу своєчасно впливати на навчальну діяльність студентів, коригувати проблеми в навчанні, а найголовніше-розвивати у студентів усвідомлення доцільності систематичної самостійної роботи.

На даний час робочими навчальними програмами не передбачено обов'язкове використання студентами сервера дистанційного навчання БДМУ під час самостійної роботи, проте сервер користується неабиякою популярністю серед студенства. Результати опитування, яке було проведено у лютому 2013 року, засвідчило, що близько 90 \% студентів щодня використовують сервер при підготовці до навчальних занять. На сервері за даними сервісу інтернет-статистики "Hotlog” в середньому на добу реєструється 5500 переглядів. За показниками "Рамблер ТОП 100", сервер дистанційного навчання БДМУ займає 6 місце у категорії “Дистанційна освіта”, а в категоріi “Освіта”, де зареєстровано понад 6400 сайтів та інформаційних веб-порталів, посідає 57 позицію, випереджаючи такі ресурси, як Центр дистанційної освіти фізичного факультету Московського державного університету ім. М. В. Ломоносова, Гуманітарно-економічний та інфор- 
маційно-технологічний інститут (РФ, Москва), Інститут дистанційної та додаткової освіти Ульянівського державного технічного університету, сервери дистанційної освіти Казанського державного енергетичного університету та Тульського державного університету. За рейтингом “ТopPing”, сервер дистанційного навчання БДМУ посідає 3-4 місце серед усіх сайтів Чернівецької області, поступаючись лише сайтам окремих засобів масової інформації.

\section{Лiтература}

1. Горская Н. Н. Организация самостоятельной работы студентов с использованием интернет-технологий / Н. Н. Горская, И. Д. Камскова // Проблемы информатики в образовании, управлении, экономике и технике : сб. статей XII Междунар. научно-техн. конф. - Пенза : ПДЗ, 2012. -С. 103-105.

2. Дубасенюк О. А. Інноваційні навчальні технологіїоснова модернізації університетської освіти / О. А. Дуба-
Висновок. Використання сервера дистанційного навчання БДМУ в самостійній роботі студентів дозволяє розширити можливості навчального процесу, зробити його більш змістовним та цікавим, а також закладає міцну основу для подальшого самонавчання. Потужний арсенал ресурсів, елементів та модулів сервера забезпечує ефективну організацію, керівництво та контроль самостійної роботи студентів.

сенюк // Освітні інноваційні технології у процесі викладання навчальних дисциплін : зб. наук.-метод. праць / за ред. О. А. Дубасенюк. - Житомир : Вид-во ЖДУ, 2004.-С. 3-14. 3. Костикова М. В. Использование системы Moodle при дистанционной организации самостоятельной работы студентов / М. В. Костикова, И. В. Скрипина // Системи обробки інформації.-2010. - Вип. 7 (88). -С. 117-120. 